\title{
Editorial
}

\section{Special Issue: Recent Developments in Finance and Banking after the 2008 Crisis}

\author{
Nicholas Apergis ${ }^{1, *}$, James Earl Payne ${ }^{2, *}$ \\ 1 Business School, Northumbria University, Newcastle upon Tyne, NE1 8ST, UK \\ 2 J. Whitney Bunting College of Business, Georgia College \& State University, Milledgeville, GA \\ 31061, USA \\ * Authors to whom correspondence should be addressed; \\ E-Mails: nicholas.apergis@northumbria.ac.uk (N.A.); james.payne@gcsu.edu (J.E.P.); \\ Tel.: +44-(0)191-349-5536 (N.A.); +1-478-445-5497 (J.E.P).
}

Received: 11 May 2015 / Accepted: 11 May 2015 / Published: 13 May 2015

\section{Symposium Introduction}

The sub-prime financial crisis was not simply the result of excessive leverage and inadequate capital, but it was brewing for some time as a result of a gradual deterioration of business leadership, lapses in governance and in the regulatory framework (particularly in derivatives markets), and an ineffective risk-management framework. The consequences of the crisis on the operations associated with financial intermediation and markets will be felt for many years to come in reshaping the financial sector in numerous ways. The financial crisis has delivered a blow to the widely held view that the invisible hand of the market would work to make market players resolve conflicts through market discipline. It was soon realized that not only was financial market information incomplete, but that the market could be manipulated by market players. This failure, led in part by financial innovation, undermined the effectiveness of a regulatory model that rested on transparency, disclosure, and market discipline to curb excessive risk taking. Both the development of efficient legal and economic institutions and a sound governance framework are important for the emergence and growth of a sound financial system. Given the moral hazard and agency problems associated with equity-based financial contracts, institutions and governance become even more important in developing a risk-sharing financial system. The resulting reduced uncertainty is expected to encourage economic agents to engage in risk sharing contracts and thus to curtail potentially catastrophic financial events.

The first paper in the symposium entitled "Transaction-Cost Models in Continuous-Time Markets" by Thomas Poufinas attempts to explain the behaviour of transaction-cost models in periods of high 
uncertainty. The paper documents the existence of trading strategies that achieve a particular wealth level within the context of continuous-time markets. The results are relevant for the pricing of options with transaction costs, especially when such costs reach astronomical high levels during stressful events.

The second paper, "Sovereign Credit Risk and Stock Markets_-Does the Markets' Dependency Increase with Financial Distress?" by Paulo Pereira da Silva, addresses the relationship between stock markets and credit default swaps (CDS) markets, prior to and after the recent financial crisis. His analysis attempts to gauge if the co-movements between stock prices and sovereign CDS spreads increase with the deterioration of the credit quality of sovereign debt. Using the analysis of correlations, Granger causality, cointegration, and the results of an error-correction model represented in a state space form, his findings highlight a close link between these markets; however, the co-movements do not increase in periods of financial distress. His analysis does not support the hypothesis that volatility propagation necessarily increases during periods of financial distress.

The third paper, "New Evidence on the Information and Predictive Content of the Baltic Dry Index" by Nicholas Apergis and James E. Payne, analyses the information and predictive content of the Baltic Dry Index (BDI) with respect to a range of financial assets and the macroeconomy. By using panel methodological approaches and daily data, the empirical analysis documents the joint predictive capacity of the BDI for both financial assets and industrial production. Moreover, the empirical findings reveal the role of the BDI in predicting the future course of the real economy.

The fourth paper, "Quantity versus Price Rationing of Credit: An Empirical Test" by George A. Waters, considers the comparison between two alternative proxies for price rationing of credit, i.e., an aggregation of information on interest rates versus loan officer survey data. The implications are important in cases in which some borrowers are denied loans, especially during financially stressful periods. His results show that the loan officer survey data serves as a better leading indicator of credit market conditions that affect real activity.

Last but not least, the fifth paper, "Decomposing U.S. Money Supply Changes Since the Financial Crisis" by Richard Robinson and Marwan El Nasse, argues that in response to the financial crisis of 2008, the Federal Reserve radically increased the monetary base, while banking institutions responded by increasing excess reserves rather than increasing bank loans, and the public responded with a substantial flight to liquidity in the form of currency and demand deposits. As a result, money supply multipliers substantially decreased, so that the actual money supply measures grew more moderately than the base. The sustained multiplier collapse spawned the re-examination of monetary versus fiscal theories of price-level determination. Their empirical analysis present decompositions of the money multiplier collapse into changes in the currency-to-deposit ratio and the reserve-to-deposit ratio. By doing so, possible near-term increases in the multipliers are simulated so that the possibility of either full or partial restoration to their pre-crisis levels is assessed. Their findings illustrate the Federal Reserve's exit dilemma that resulted from its financial-crisis policy.

(C) 2015 by the authors; licensee MDPI, Basel, Switzerland. This article is an open access article distributed under the terms and conditions of the Creative Commons Attribution license (http://creativecommons.org/licenses/by/4.0/). 